\title{
Day Times Nanomole Per Liter Per Milligram Per Gram Per Day
}

National Cancer Institute

\section{Source}

National Cancer Institute. Day Times Nanomole Per Liter Per Milligram Per Gram Per

Day. NCl Thesaurus. Code C117907.

Day times nanomole per liter, divided by milligram per gram per day. 